\title{
From troops to teachers: changing careers and narrative identities
}

\begin{abstract}
Troops to Teachers is a UK governmental scheme introduced in 2013 to facilitate ex-military service personal to re-train as teachers. This study explores the narratives of a sample of new $T t T$ trainees at the outset of their training and considers their motivations for career changing, potential transferable attributes and skills, aspirational teacher identities and anticipated challenges. Emerging from these rich narratives is a strong, shared commitment to the trainees' chosen new career. Self-discipline is identified as a professional quality to take into teaching from military service, whilst maintaining discipline in the classroom is more commonly regarded as an area of concern and challenge, rather than as a transferable skill set, challenging perhaps core governmental expectations of the Troops to Teachers initiative. However, the importance of and a desire and commitment to continue to 'serve', is widely held and this provides potential for further, perhaps longitudinal study as the troops become teachers.
\end{abstract}

\section{Key words}

Career change teachers; troops to teachers; narrative; professionality.

\section{Author}

Mark Price is Principal Lecturer in the Education Research Centre, School of Education, University of Brighton, UK.

School of Education

Checkland Building

University of Brighton

Falmer

Brighton

BN1 9PH

Email: m.price@brighton.ac.uk

Tel: +44 (0)1273 643319

ORCID identifier: 0000-0001-9512-1902 


\section{From troops to teachers: changing careers and narrative identities}

\section{Introduction}

The paper considers anticipated teacher self-identities for career changing trainee teachers at the outset of their professional training. Specifically, the study presented focuses on trainees recruited as part of the UK's national Troops to Teachers (TtT) scheme.

Troops to Teachers was launched jointly by the Department for Education and Ministry of Defence in June 2013, taking its inspiration from the USA's Troops to Teachers programme, 'Proud to Serve Again', established in 1993. The UK TtT programme aims to 'provide teacher training opportunities to service leavers, with significant extra benefits including salaries while training, bursaries and bespoke training' (DfE/MoD, 2013).

At its launch, the then Education Minister, David Laws, revealed the rationale behind the TtT programme:

Many members of our inspiring armed forces possess the skills and expertise relevant and transferable to the classroom - leadership, discipline, motivation and teamwork. Every child can benefit from having these values instilled in them.

We want to capture the ethos and talents of those leaving the armed forces, and bring this experience into teaching. We know that our highly-skilled servicemen and women can inspire young people and help raise educational attainment.

Troops to Teachers will make it easier for those who have already contributed so much to our country to continue their brilliant work - this time in the classroom.

(DfE/MoD, 2013)

It is the DfE./MoD's assertion that TtT trainees will bring transferable skills, expertise and values into teaching, combined with the potential to inspire and motivate children and young people, which contributes to the impetus for this study.

The purpose of this narrative study therefore, is to explore the range of previous experiences and associated attributes and 'skill sets', ex-service personnel identify that they are bringing with them into their new career as teachers. Alongside this, is a broader exploration of projected identities as teachers and the anticipate processes of career changing, facilitated by 
the TtT programme. The study is situated within and seeks to contribute to debates relating to meeting future teacher recruitment needs in the UK (House of Commons, 2017), the potential implications of the TtT strategy and broader educational issues such as the promotion of 'British values' (DfE, 2014) and issues relating to national and global citizenship. The intention is also that this study provides a platform for a longer study into the process of reprofessionalisation for $\mathrm{TtT}$ career changers.

\section{From troops to teachers}

In the UK, TtT is currently one of a number of routes, endorsed and recognised through the National College of Teaching and Leadership ${ }^{1}$, leading to trainees becoming qualified to teach in schools in England and Wales. These routes include both undergraduate and postgraduate, school based and university based programmes. The TtT programme comprises two years of professional study leading to an honours degree with 'Qualified Teacher Status' (QTS) and requires applicants to have prior academic experience and qualification to a minimum or equivalent to one full-time year study in higher education.

Applicants come to the UK TtT programme having previously held a range of combatant and non-combatant roles in the military services. All are required to have served for a minimum of four years and at the start of the programme, applicants must be within five years of their discharge date.

Evaluative studies (Owings, Kaplan, Nunnery, Marzano, Myran and Blackburn, 2006; Owings, Kaplan, Khrabrova and Chappell, 2015) of the USA Troups to Teachers programme have been positive, affirming that:

TTTs continue to seek and hold positions in high-needs schools teaching high-demand subjects while using research-based instructional and classroom management strategies. Their supervising administrators confirm their instructional and classroom management effectiveness and their contributions to the school as a whole.

(Owings et al., 2015, p.92)

Whilst levels of need in terms of teacher recruitment and social challenges may differ, nonetheless, the potential for the USA programme to offer a possible blueprint for the UK is clear. Since its inception however, the UK TtT programme has not been without its critics. Smith, (2012), Chadderton (2014) and Tipping (2016) among others, question the strategy 
which appears to legitimise the view that a solution to a pervasive unruly underclass in schools is to champion traditional values of self-discipline, modelled by ex-service staff.

This study does not seek directly to either respond or add to these critical voices, but rather places the narratives of TtT recruits at the very onset of their training, in the context of such concerns, and considers how the ex-service personnel themselves feel they can make the change and make a difference.

\section{Career changers and changing professional identity}

For many working in what has been termed this 'post-professional' age (Hargreaves, 2000), identities are by necessity, 'characterised by flux, with stability being more elusive, while openness to change is a more definite requirement' (Sugrue and Solbrekke, 2011, p.ix). Wilkins et al (2012) observe that in constructing and re-constructing professional identities, a process of meanings and practices are explored through 'constant role-taking, role exchange and negotiation of shared symbols and shared meanings' (ibid., p.69) This reflects a process of co-construction of identity and one where understandings of roles being formed, are shaped and informed by experiences and previously held positions and identities (Wilkins et al., 2012; Price 2015). Williams (2010) highlights more specifically, how career changers may bring a range of skills and interactions relating to 'human behaviour', which they are then able to build upon in their second or new career, especially where this is particularly valued by the career changer's new profession.

Hence, this study is situated within the context of key academic debates over the reconceptualisation of routes to professionalisation and of professionality in the public sector (e.g. Evetts, 2013; Noordegraaf, 2013; McNamara, Murray and Jones, 2014). The study aims to contribute knowledge which informs and influences these debates in the UK and internationally, and enhances understanding of the relationships between vocation, training, higher education and public service professionalism.

\section{Focus and method}

The primary approach taken with this narrative study (Clandinin and Connelly, 2000; Goodson, 2013), was to develop a series of individual 'portrayals' of the developing reflections and identities of a sample of TtT recruits at the outset of the programme. 
An opportunistic sampling approach was adopted. During their induction week, new TtT trainees were invited to join the study and 12 trainees (approximately $10 \%$ of the total cohort) subsequently confirmed their consent to participate, including permission to use as research data, a 500-word autobiographical 'pen portrait', written as a pre-course task.

Ages of the participants vary between 23 and 55 years and include eight men and four women, of which six are training to become primary education teachers and six as secondary education teachers. The subject specialisms of the secondary education trainee teachers include history, religious education (x2), physical education, art and physics.

The service experience of participants varies considerably and includes: training and instruction; translation; anti-piracy work; counter intelligence; international defence strategy; photography and surveying; and in some cases, active combat. Those participating included both commissioned and non-commissioned officers.

Within four weeks of the start of their TtT training, all 12 trainees were interviewed by telephone for approximately 45 minutes each. These semi-structured telephone interviews focused on two broad areas of questioning:

- Tell me about your route into teaching. Why do you want to become a teacher?

- What do you imagine you'll be like as a teacher and what kind of teacher do you hope to become? And in what ways do you think your previous profession (identity, attributes and skills) will influence or play a part in your developing identity and role as a teacher?

Each interview was recorded using an electronic audio recording device, transcribed and the transcription then emailed to the particular participant. Following receipt of their transcribed interview, the participant was then invited to offer further reflections and analysis by email. Institutional ethical approval was gained for the study as a whole and all participants granted individual approval for inclusion of transcribed and written data. All data (interview transcripts, email exchanges, pen portraits) were anonymised, identifiers removed and names changed. 
Portrayals were then developed for each participant from analysis of the interview transcription, email exchanges and pen portrait, according to the following themes, reflecting the aims of the study and influenced by previous narrative research by the author (Price 2015; 2017):

- coming into teaching: motivation, previous experiences, events and relationships which played a part in committing to the TtT programme;

- transferable elements: values, qualities and attributes (including specific knowledge and skills) from previous experiences, identities and careers, seen as relevant and/or transferable;

- projected practice and identity: the teacher the trainee hopes and expects to become;

- anticipate challenges: in terms of becoming a teacher, the process of professional training and development and changes in professional focus and identity.

An overarching, meta-analysis of the 12 individual narratives, was subsequently developed. It is this meta-analysis which this paper considers and presents.

\section{Narrative inquiry}

Narrative methodologies embrace a range of processes and positions. Speedy (2008) explores the key themes of reflexivity and liminality in relation to narrative inquiry, when she notes that 'we are continuously engaging in the spaces that which is known and that which is not yet known' (ibid. p.28). Hence, the nature of narrative professional formation can be considered to be an 'autoetymographical' one - we choose and use words to represent our changing truth and meaning.

Goodson and Hargreaves (1996) and Day et al. (2006) amongst others, note that for teachers, professional identities and selves are constructed from the process of changing professional practice, situated in the context of personal experiences, culture, values and identities. In exploring this construction process, Clandinin and Connelly (2000, pp.2-3) see narrative inquiry as 'to move back and forth between the personal and the social, simultaneously thinking about the past, present and future'. This process of professional formation involves such a shift between personal and professional experiences, practices and identities. It requires participants to re-construct their own personal-professional narrative through loosely structured interviews (Sfard and Prusak, 2005) in relation to 'border’ (Connelly and 
Clandinin, 1999) and/or 'boundary' (Kerosuo and Engeström, 2003) crossing. Hence, the approach taken is a collaborative process of co-construction. Data collection (participants reflecting on their motivations and experiences) and data analysis (further collaborative analysis of the narrative) at times interweave through the dialogical relationship.

Etherington (2004) makes the point that narrative analysis (as opposed to analysis of narrative) 'views life as constructed and experienced through the telling and re-telling of the story' (ibid., p.213). Hence, in telling their story, the participants, the TtT trainees, construct their reality. Their story or narrative thus includes both their identified reality and their developed analysis; their constructed self.

\section{Analysis across the narratives: motivations, aspirations and making the transition into teaching}

Each participant's co-constructed narrative is individualised and personal, with a diversity of motivations, aspirations and changing professional identities evident across the $12 \mathrm{TtT}$ trainees interviewed. Some draw on childhood influences on a career in teaching, whilst others make explicit reference to aspects of military service, both in shaping career choices but also in potentially influencing teacher identity development. The approach taken here is to look at overarching themes, including emergent issues which give some indication as to the potential for further, more longitudinal research into the narrative development of TtT career changers.

\section{Motivations}

Several of the trainees identified a long standing interest in teaching, including for some, predating their military service career. Lucy reflects “I think it’s just been a bit of natural progress really" whilst Ward asserts more strongly perhaps "it was the plan from school; my aim ... was always to go into secondary teaching."

For others though, choosing teaching has come more 'out of the blue'. Karen notes that she "kind of fell into it by accident”, reflecting that "my own experience of school was mixed". For Susan "it was a couple of girls that I played hockey with that were PE teachers; they said this would be a good career for you and it wasn't something I'd ever thought of”, whilst Roger notes “it wasn’t really an initial aspiration to be honest”. 
Caroline's impetus to move into teaching arose from experiences of working with children within her military role:

we were getting work experience children, so sort of year 10 children coming into the photo section thinking about joining the Air Force or wanting to become a photographer. So I took them under my wing when they were with us and I would teach them how to use a camera and we would go out and do little projects together and a lot of them would always want to come back over the summer holidays cos they enjoyed themselves

Other trainees were attracted to teaching through the experience of going into schools on the back of their service experience. Richard gives an account of finding himself:

with time on my hands and I was looking around thinking what could I do and, a military guy reached out and said "look we do a military ethos programme where we go into schools and we teach them military ethos. You know map reading, resilience, discipline, soft discipline these sorts of things, would you like to take part in it?” and I was like “oh, OK, I’ll give it a go, why not?"

Simon's route into teaching is not dissimilar:

My route into teaching, I suppose it was kind of random really. It's quite lucky that the Troops to Teachers programme exists otherwise I don't think I would have pursued it ... I was on leave from my job and I was bored and wanted something to do so I went to school and asked if I could volunteer. They knew I was an ex-marine so they gradually pushed me towards the naughty kids and behaviour mentoring. And then the Troops to Teachers thing came around then and I thought "well, I'll give it a go"

Perhaps a key common factor here is both Richard and Simon's willingness to 'give it a go', as a result of $\mathrm{TtT}$ being an opportunity afforded to them as ex-service personnel.

For Alan, it was his experience as a father which inspired him to consider teaching: "seeing my child have those moments when it clicked or he's realised something and just seeing him grow in his education, it got me quite inspired to go into education myself”. Christopher too, was motivated to apply to the TtT programme through getting involved in his son's sports activities:

I thoroughly enjoyed it and really got on well with the boys and seemed to get on better with them as they got older ... I really enjoyed that aspect, albeit only in a football and a rugby setting but I enjoyed building a team, the team building and the camaraderie side 
of things and I thoroughly enjoyed their company. I think that gave me confidence of being around children

There was a broader issue amongst some of those interviewed, regarding possible alternatives on leaving the military, as other options to be considered alongside teaching. Roger describes his original plan to move on from a career in counter intelligence data analysis:

You know my whole idea was to seamlessly move from what I had been doing into another different government agency and continue my career. But realistically after a number of routes down various selection processes, I realised I was being offered things which were not what really what I was interested in doing ... and I really had to decide at that point what I really wanted to do.

Similarly, Christopher reflects on a possible 'next steps' after a long career in the Royal Navy:

when I first thought about what I was going to do, I thought I would go into the commercial world because that's what a lot of peers who have been in the armed forces for as long as I have at my rank, because I was a commissioned officer, would go into a commercial world - commerce or the defence industry, defence procurement industry, something like that...

Christopher continues though and comments here on a motivation to contribute to or be 'of value' to society:

... but the more I looked into that and thought about it and felt about it, the less appetising, if that's the right word, it was. You know I wasn't particularly driven my money although money is clearly a factor ... but I wasn't driven by a great desire to go out and earn huge amounts of money. I wanted something to be honest, that I thought was going to make a bit of a difference. Bit of a cliché I'm afraid, but I did want to try and make a little bit of a difference to society and perhaps contribute in my own small way to making people's, and particularly children's lives, better.

Here Christopher touches on a theme which emerges from many of the TtT trainees' narratives, that of wanting to continue to be in or of 'service'. Richard echoes this but broadens his analysis away from his own to personal motivation to that of ex-service personnel more widely: “it’s probably servicemen in general, as we have a mentality of service and it's looking at something other than ourselves; it's looking at the bigger picture”. The concept of 'service' presented by the trainees here reflects to some extent a discourse of trust, commitment and altruism, embodied within public perceptions of occupational 
professionalism (Evetts, 2013). The trainees acknowledge this within the military role they are leaving and regard teaching as offering the potential to maintain this professional service, albeit within a new occupational focus.

\section{Transferable experiences, attributes and skills}

For some of the trainees, there was a clear progression from their military career and role into that of teaching. Ward recounts that he'd "spent quite a while in the Marines instructing, and I took a great deal from that”. Susan's career too had “ended up in a regimental training wing”. It perhaps here then, that there is the potential for the most coherent sense of a transferable skill set. Stephen's narrative exemplifies this:

And during my time in the army ... I spent a lot of time in training. I also set up the Royal Artillery Centre for government apprenticeships in heavy goods vehicles and logistics. When I left, just before I left, I ran the army's training for their management accountants. So I've always been into the training piece and I understood how important education was and I'd worked with the British Forces, German Youth Service, I've enjoyed the work with the young people there, I've worked with some cadets forces in the UK. So there's this link of, I'd understood the importance of education, having had a poor education myself, then I understood the importance of training from the army and then this other element of working with young people.

As well as a particularly potentially transferable pedagogic skill set, most commonly relating to previous instruction and training roles, some of the trainees have already had experience of sharing a little of their military careers with children in school. After serving in counter intelligence, Lucy is now training to become a history teacher:

I introduced myself to the kids and told them who I was and it's been really positive feedback and they've actually all ended up showing what they are interested in. We've ended up talking about history and political history and politics and things like that and they're learning without realising they are because I've been talking about military and politics and terrorism and things like that with them, and they've been really engaged and asking questions and wanting to talk about it and they're not realising they're learning stuff.

Ward sees the potential for the richness of experiences arising from his time as a Marine, becoming a resource for his teaching:

I've got a lot to offer having gone through two wars ... there's a lot of experience there. I've travelled the world and I've built up a lot of personal experience within the Marines, which I can then channel towards a younger generation of kids and hopefully 
give them some of my passion, my passion for life and passion for knowledge and education.

Richard is the only trainee to comment specifically on how ex-service personnel moving into teaching might be regarded negatively:

I've read lots of articles about the militarisation of children in schools by lots of teachers that think soldiers should stay well away from schools and the MOD and the education department were funding these things so we can have an influence and convert children to become soldiers cos they need soldiers in the future and we're gonna brainwash them and stuff.

Richard counters this though with: "when they do encounter us, I mean I've been at my school for four months now and I've made a lot of close friends, a lot of close friends and they are like 'you're quite nice, you're a human being'”’.

Discipline management was cited specifically (DfE/MoD, 2013) as an anticipated transferable skill. However, none of those interviewed regard any experience and/or skill set relating to maintaining discipline within their military service, as being relevant to this aspect of their new career in teaching.

Karen does though acknowledge how her military service has engendered a self-discipline which she takes into teaching: "but it's definitely given me the drive and it's given me a lot of the tools that I need for this course; the kind of, the discipline. I know I've got work due so I'm going to do the work".

There was other evidence among some trainees, of identification of a range of what are regarded as relevant personal qualities/attributes (e.g. organisational skills; resilience; commitment), considered to being of value and to be taken into teaching. Richard summarises this as "it's another thing we do - we are multi-skilled".

The notion of a relevant skill set that can be transferred from a military to a pedagogic role, from a governmental perspective (DfE/MoD, 2013), is a significant and attractive element of the $\mathrm{TtT}$ programme, reflecting a broader reconfiguration of professionalism in public services (Noordegraaf, 2016). For the individual TtT trainees, the challenge will be to re-situate any 
perceived transferable skills as ‘expert novices' (Williams, 2010) within a new occupational context and practice.

\section{The teacher I want to become}

The theme of becoming a creative, adaptable, enthusing, inspiring teacher is common to all, and is probably true of most going into teaching, not just TtT trainees. Ward's enthusiasm represents that of the trainees generally:

I wanna be the one they remember so in years, when they come out of secondary school, they're in college, they're doing this and that, they're walking past me in the street and they're saying 'Mr xxxx, thank you'. I can't think of any better compliment than that.

One of the questions I asked of all the trainees during their interviews was what would I see if I came into their classroom in two years time. Again, Ward's enthusiasm and projected professionality is palpable and again is representative of many of the narratives:

You'd see a class who are fully engaged, fully enthused, there's full inclusion. Smiling faces and a learning environment in which I'd hope that even you as an adult would want to sit down and engage in. I want a vibrant classroom. I want a classroom where anyone who walks in they see the kids, they see their attitudes, they see the happiness in there, but they also see the work ethic in there. And a place in which you know you just wanna sit down and learn and someone you wanna learn from.

For some, the passion is for their subject:

I had a young girl and she said to me 'oh, I don't need RE'. I said 'you do, you need it for the wider world' and blah blah and she said 'well yeah I'm not going to stay in this village forever, I am gonna move away'. I said 'oh right, where are you going to move to?' And she went, "well xxxxxx", which is about twenty miles down the road, and I just thought "well”; inside I kind of thought "xxxxxx"s not that far", but in her world that is like the other side of the universe, twenty miles away ... I think a lot of that is about helping people understand other people and understanding what connects us. What's the same but also what at times is different and understanding those differences.

(Karen: secondary RE teacher)

Once I'd started my studies, people would ask me 'why physics?' as if I'd gone mad. This made me realise that there's a stigma with the subject; that it's either boring or you have to be really clever to understand it. Please don't take me the wrong way, I haven't found my studies to be a breeze in the park, but I've enjoyed learning more about the subject and I feel that has given me a greater understanding in learning, in hard work 
and in determination; that is what I aspire to bring to the classroom, whist trying to make it an enjoyable experience for the students in the process.

(Caroline: secondary physics teacher)

I want to be that kind of PE teacher that makes pupils want to come to PE and try something new and when they find something new that they are good at and they take those lessons on in life they can sort of think back and think that was because of that teacher I had.

(Susan: secondary PE teacher)

\section{Challenges}

For several of the trainees, the academic demands of the course are regarded as being a significant challenge. Jimmy concedes:

The academic side is not something I've ever been very good at. Like I said, I like to work hard and usually if you work hard things happen. But if you're not very good at things, it doesn't matter how hard you work; that's my biggest worry.

Ward is training to become a primary school teacher and for him, specifically the challenge is in subject knowledge:

Subject knowledge has got to improve, you know yourself once your subject knowledge is great and you're confident in delivering a subject or topic, then everything else comes a lot easier. So the subject knowledge is the big one.

Several express apprehension regarding maintaining ‘discipline’ within the classroom. Jimmy observes “there's a difference in shouting at a full grown adult to make them do a press up or something. You can't take that same approach with a small child”. Later he returns to this theme:

Personally I can't see a connection. Before I'd seen anything to do with teaching my instinct was yeah, of course get soldiers in the classroom cos they will discipline and then now I'm in that position myself I'm thinking, well actually it's not the same as telling a group of trained soldiers what to do. It's telling a bunch of kids and if they don't want to do it, you can't just shout at them.

Amongst the older trainees perhaps, predominantly those in the late 40s and earlier to mid 50 s, there was a wish to assert a lack of aspiration regarding career progression within teaching. This is certainly the case of Roger ("I'm less concerned about advancement in this 
career”) and Christopher, who expresses his alarm at being regarded as potential leadership material, because of his successful military career:

my headteacher, lovely guy that he is, seriously a very nice man, but once or twice he's said “you know we're looking for, you know with your background and experience and leadership and management skills we're really hoping you'll be able to bring things to the school”. And I'm thinking “crikey, what do I need to do to do that?!”

Roger and Christopher evidence an emergent theme of a motivation common among the trainees, to teach and be 'of service', rather than necessarily to advancing a career in teaching.

\section{Conclusions}

All the participants in the study present an enthusiasm and commitment to their chosen change of career. They appear well motivated and have an articulated sense of the teachers they wish to become, including the challenges they feel they will face.

Whilst there was no obvious consensus regarding an ex-service 'skill set' being readily transferable from a military career into teaching, the dispositions of being organised and selfdisciplined were often mentioned. However, a distinction was clearly made between being self disciplined and being able to engender discipline as a teacher as a result of military service experience. To the contrary, several of those participating in the study, identified classroom management and maintaining discipline as an anticipated challenge. This would appear to some degree to counter the governmental aspiration of the TtT programme for troops to bring discipline into the classroom.

Those with previous roles in military instruction and training, regard teaching as something of a progression, with a possible set of transferable skills. More broadly perhaps, several identified being a 'team player' as being a transferable quality to take from their military service into teaching.

What appears interesting though as an emergent theme and one worthy perhaps of further study as these troops become teachers, is the wish that several expressed that following their military service, they would continue to be 'in service' or 'of service' to society. It is suggested that this motivation, voiced in different ways through the TtT trainees' narratives, 
reflects something of a professional, narrative 'refraction' (Goodson and Rudd, 2012); that troops see teaching as means or opportunity to be of service once more, reflecting a fundamental, defining feature of their professional military identity. This refraction is represented most obviously through the strap-line of the US TtT programme, on which the UK programme is modelled, 'Proud to serve again'. For the trainees to become teachers, this commitment to service potentially shapes future constructions of teacher professionalism, as the trainees experience the culture and practices of schools and the classroom (Wilkins et al, 2012).

\section{References}

Chadderton, C. (2014) 'The militarisation of English schools: Troops to Teaching and the implications for Initial Teacher Education and race equality', Race Ethnicity and

Clandinin, D.J. and Connelly, F. M. (2000) Narrative Inquiry: Experience and Story in Qualitative Research San Francisco: Jossey-Bass

Connelly, M. and Clandinin, J. (eds) (1999). Shaping a professional Identity: Stories of Educational practice. New York: Teachers College Press.

Day, C., Kington, A,, Stobart, G. and Sammons, P. (2006) 'The personal and professional selves of teachers: stable and unstable identities’ British Educational Research Journal, 32(4); pp.601-616

Department for Education (2014) Promoting fundamental British values as part of SMSC in schools Departmental advice for maintained schools. Available online:

<https://www.gov.uk/government/uploads/system/uploads/attachment_data/file/380595/ SMSC_Guidance_Maintained_Schools.pdf $>$ [Accessed: 24 ${ }^{\text {th }}$ July 2017]

Department for Education / Ministry of Defence (2013) New routes for talented ex-armed forces personnel to become teachers London: GOV.UK. Available online: $<$ https://www.gov.uk/government/news/new-routes-for-talented-ex-armed-forcespersonnel-to-become-teachers $>$ [Accessed: 24 ${ }^{\text {th }}$ July 2017]

Ellis, C.S. (2008) 'Co-Constructed Narrative’ in Given, L.M. (ed) (2008) The Sage Encyclopedia of Qualitative Research Methods London: Sage

Etherington, K. (2004) Becoming a Reflexive Researcher: Using Our Selves in Research London: Jessica Kinglsey

Evetts, J. (2013) 'Professionalism: Value and ideology', Current Sociology Review 61(5-6) pp.778-796

Goodson, I.F (2013) Developing Narrative Theory: Life histories and person representation Abingdon: Routledge

Goodson, I.F. and Hargreaves, A. (1996) Teachers' Professional Lives Abingdon: RoutledgeFalmer

Goodson, I. and Rudd, T. (2012) ‘Developing a concept of ‘refraction’: exploring educational change and oppositional practice’ Educational Practice and Theory, 34 (1). pp. 5-24. 
Hargreaves, A. (2000) 'Four Ages of Professionalism and Professional Learning’ Teachers and Teaching: History and Practice, 6(2); pp.151-182

House of Commons Education Committee (2017) Recruitment and retention of teachers:

Fifth Report of Session 2016-17 Available online:

<https://www.publications.parliament.uk/pa/cm201617/cmselect/cmeduc/199/19902.ht

$\underline{m}>$ [Accessed: 24 ${ }^{\text {th }}$ July 2017]

Jeong-Hee Kim (2015) Understanding Narrative Inquiry: The Crafting and Analysis of Stories as Research, London: Sage

Kerosuo, H. and Engeström, Y. (2003) 'Boundary crossing and learning in creation of new work practice’, Journal of Workplace Learning, 15(7-8); pp.345-351

McNamara, O., Murray, J., and Jones, M. (Eds.) (2014) Workplace Learning in Teacher Education, London: Springer

Noordegraaf, M. (2013) 'Reconfiguring Professional Work: Changing Forms of Professionalism in Public Services', Administration \& Society 48(7) pp.783-810

Owings, W. A., Kaplan, L. S., Nunnery, J., Marzano, R., Myran, S., and Blackburn, D. (2006) 'Teacher quality and Troops to Teachers: A national study with implications for principals’ NASSP Bulletin, 90, pp.102-131.

Owings, W. A., Kaplan, L. S., Khrabrova, I. and Chappell, S. (2015) 'Troops to Teachers Update: Changing, but Still Pleasing Principals With High Teaching Quality’ NASSP Bulletin, 99(1), pp.70-98.

Price, M. (2015) 'Becoming a Youth Practitioner: A Narrative Study of Personalized Constructions of Professionalism and Professional Identity Formation', International Journal of Interdisciplinary Social and Community Studies, 10(2), pp.1-12

Price, M. (2017) 'Youth Practitioner Professional Narratives: Changing Identities in Changing Times’ British Journal of Educational Studies pp.1-16

Sfard, A. and Prusak, A. (2005) 'Telling Identities: in search of an analytic tool for investigating learning as a culturally shapes activity’ Educational Researcher 34(4); pp.14-22

Smith, P. (2012) 'Troops to Teaching: lessons from English teaching assistants' experiences of foundation degree study' Journal of Education for Teaching 38(5), pp.525-537

Speedy, J. (2008) Narrative Inquiry and Psychotherapy Basingstoke: Palgrave Macmillan Sugrue, C. and Solbrekke, T. D. (Eds) (2011) Professional Responsibility: New Horizons of Praxis, Abingdon: Routledge

Tipping, A. (2013) “"Troops to Teachers”: implications for the coalition government's approach to education policy and pedagogical beliefs and practice', Educational Studies, 39(4), pp.468-478

Wilkins, C., Busher, H., Kakos, M., Mohamed, C. and Smith, J. (2012) 'Crossing borders: new teachers co-constructing professional identity in performative times', Professional Development in Education, 38(1), pp.65-77

Williams, J. (2010) 'Constructing a new professional identity: Career change into teaching', Teaching and Teacher Education, 26, pp.639-647

\footnotetext{
${ }^{1}$ The National College of Teaching and Leadership is not a 'college' in the common sense but rather an executive agency of the UK's Department for Education.
} 